\title{
Feasibility of Using Waste Sweet Bay Wood (Laurus nobilis L.) in Particleboard Production
}

\author{
Hikmet Yazici*
}

Turkey holds a 95\% market share of global sweet bay (Laurus nobilis L.) leaf trade, and it has 25 leaf processing and manufacturing facilities with different capacities. In this study, the usability of waste sweet bay wood (BW) that was removed from bay leaf processing plants was studied. For this purpose, three-layer particleboards were produced by mixing industrial chips (IC) and waste sweet bay wood chips (BWC) at a mixture rate of $0 \%$, $25 \%, 50 \%, 75 \%$, and $100 \%$. For panel production, urea formaldehyde adhesive (UF) was used in $10 \%$ of the surface layers and in $8 \%$ of the middle layer based on dry chip weight. Some mechanical properties, such as bending strength (BS), modulus of elasticity in bending (MOE), internal bond strength (IB) of the test panels, thickness swelling (TS), and water absorption (WA) amounts, were determined. The results showed that all panel groups except group C (25\% BWC $+75 \%$ IC) met the general purpose panel class $(\mathrm{P} 1)$ requirements for use in dry conditions according to TS EN 312 (2012). In addition, group A panels (100\% BWC) met the requirements of $\mathrm{P} 2$ class for the MOE and $\mathrm{BS}$, and group $\mathrm{E}$ panels $(75 \%$ $\mathrm{BWC}+25 \%$ IC) met the P3 standards. The results showed that BWC could be used to produce particleboard for general purposes, including furniture.

Keywords: Laurus nobilis; Particleboard; Waste wood; Mechanical properties; Thickness swelling; Bending strength

Contact information: Design Department, Interior Design Program, Zonguldak Bülent Ecevit University, Çaycuma Vocational School, Çaycuma 67900 Turkey; *Corresponding author: hikmet.yazici@beun.edu.tr

\section{INTRODUCTION}

Particleboard is a wood-based material produced by the gluing of wood particles and other lignocellulosic raw materials. It is widely used worldwide for structural purposes, flooring systems, and furniture (Youngquist 1999; İstek et al. 2017a, 2019). As the demand for various wood panel products has increased due to recent increases in population, the effort to find alternative raw mateiral sources remains an important issue because wood raw material obtained directly from forests is insufficient. To solve the raw material problem and meet the future demand for wood-based products, industrial residues, nonwood materials, agricultural residues, fast growing trees, and underutilized wood species are being used (Nasser 2012; Fiorelli et al. 2012; Dos Santos et al. 2014; Yano et al. 2020). In addition, the emergence of a significant amount of waste that can be reused or recycled due to forestry industry practices has also focused on this area, and the conversion of wood waste into usable products has been studied for decades (Clausen 2000; Khedari et al. 2004; Dos Santos et al. 2014; Zayed et al. 2015; Kurt 2020). Today, agricultural and other lignocellulosic wastes are generally burned, disposed of, or used to obtain energy. All of these methods can cause soil and air pollution, and environmental damage is caused by carbon emissions. In addition, an important raw material source disappears before it turns 
into a value-added product (Nazerian et al. 2016; Sugahara et al. 2019). Particleboard is an important wood-based material that can be produced using low-quality materials. The production process, using the entire wood raw material with its parts, including bark and needles, results a value-added product. Thus, environmental and economic benefits are obtained (Maloney 1993; Cai et al. 2004).

Studies related to finding alternative raw materials were examined to produce wood-based boards. In particular, studies on grain, wheat straw, and corn stalk (Han et al. 1998; Wang and Sun 2002; Mo et al. 2003; Halvarsson et al. 2008), tea plant and red pine wood (Nemli and Kalaycığlu 1997; Filiz et al. 2011), sunflower stems (Khristova et al. 1998; Guler et al. 2006; Meinlschmidt et al. 2008), castor stalks (Grigoriou and Ntalos 2001), peanut husks and shells (Batalla et al. 2005; Akgül and Tozluoğlu 2008; Guler et al. 2008), almond shells (Gürü et al. 2006), horticultural, tomato, and eggplant stalk wastes (Arslan 2008; Guntekin and Karakuş 2008; Guntekin et al. 2009), rice husk (Tansey 1995; Ciannamea et al. 2010), cotton stalk and watermelon (El-Mously et al. 1999; Guler and Ozen 2004; Alma et al. 2005; Mohamed and Nasser 2008), hazelnut husks (Çöpür et al. 2007), rhododendron (Akgül and Çamlibel 2008), palm, palm leaves, and palm branches (El-Mously et al. 1993; Lin et al. 2008; Hegazy and Aref 2010), baggase (Xu et al. 2009), linen chips (flax shiv) (Papadopoulos et al. 2003), kenaf (Grigoriou et al. 2000; Xu et al. 2003), grape vine (Ntalos and Grigoriou 2002), and bamboo chips and wastes (Papadopoulos and Hague 2004; Laemlaksakul 2010; Valarelli et. al 2014), acai fruit (de Lima Mesquita et al. 2018), apple and plum orchard pruning (Kowaluk et al. 2019) and sugarcane bagasse, Pinus taeda particles and Malva fibres (Silva et al. 2018) were reviewed. These studies on wood-based composites showed that the panel properties are mostly suitable for general purposes (Kalaycioglu et al. 2005; Guler et al. 2006; Pan et al. 2007; Bardak et al. 2010; García-Ortuño et al. 2011; Guler and Büyüksari 2011; Juliana et al. 2012; Topbaşl1 and Sevinçli 2017; Guler and Beram 2018; Guler and Yaşar 2018). However, these alternative raw materials also have some disadvantages. In particular, annual plants take up a lot of space, and the panels produced from such materials may have low dimensional stability and inadequate mechanical properties (Iswanto et al. 2014). However, some mechanical properties of particleboards can be improved by using chemical additives, such as organosilanes (Onat et al. 2014).

Mediterranean sweet bay (Laurus nobilis L.) is the most important medicinal aromatic plant in Turkey, and it has an important place in foreign trade (Gökmen 1973; Kayacık 1977; Guler and Basaran 2003; Kurt et al. 2016). Bay oil and bay fruits are used in the food, beverage, pharmaceutical, chemical, and cosmetic industries (Özer 1987; Yazic1 2002). Bay leaves are usually dried and exported. According to the 2012 to 2015 year export data from Turkey, exporting 46,154 tons of bay leaves generated 134 million US\$ of income (Turkish General Directorate of Forestry, 2016). The increasing market demands of bay leaves in the world in recent years have enabled private companies to adopt bay leaf production using advanced technologies. There are 25 different facilities in Turkey that operate as bay leaf drying and processing plants. The total processing capacity of the plants is 115,000 tons/year of wet branches. When the installed capacity of businesses across Turkey is considered, approximately 46,000 tons/y of dry sweet bay wood is added to the country's total industrial waste. Most of this bay wood waste is used for energy recovery by burning. Turkey has a thriving forest products industry and major investment in the wood-based panels industry. It ranks first in Europe and globally for particleboard and fiberboard (medium-density fiberboard) production amounts (İstek et al. 2017b; İstek et al. 2018a; Kurt and Karayılmazlar 2019). In addition, research on the use of different 
lignocellulosic materials is ongoing in Turkey to meet the increasing need for raw materials. From this perspective, the detection, amount, and evaluation of lignocellulosic industrial wastes are extremely important. Wood raw material with high evaluability is the basis for the continued development of bay processing production plants. In addition, it is important that their capacity constantly increases.

In this study, the possibility of using bay wood obtained from a bay leaf processing and production facility as an industrial waste in the production of particleboard was investigated. For this purpose, some physical and mechanical properties of the particleboards produced from softwood and hardwood chips readily obtained from bay wood and particleboard plants were determined. The obtained values were compared with the requirements of standards, and the suitability of the panels was determined.

\section{EXPERIMENTAL}

\section{Materials}

In this study, bay wood waste chips (BWC) obtained from a local supplier (Defne Bitkisel Limited Company, Zonguldak, Turkey) and industrial chips (IC) (Kastamonu Integrated Particleboard Factory, Kastamonu, Turkey) supplied from the particleboard plant and consisting of softwood-hardwood wood chips were used as wood-based raw materials. A urea formaldehyde adhesive (UF) with a $65 \%$ solid content was used as the adhesive (Kastamonu Integrated Particleboard Factory, Kastamonu, Turkey). Formaldehyde glue's pH is 8.20 in E1 emission class, its density is $1265 \mathrm{~g} / \mathrm{cm}^{3}$, gel time is 54 seconds, and flow time (viscosity) is 41 vis.min. In Table 1, the average values of sweet bay (Laurus nobilis L.) and some softwood (SW)-hardwood (HW) main chemical components are shown.

Table 1. Chemical Composition (\%) of Laurus nobilis L. and Some SW-HW Wood

\begin{tabular}{|c|c|c|c|c|c|}
\hline \multirow{3}{*}{ Wood Components } & \multicolumn{3}{|c|}{ Laurus nobilis L. } & \multirow{3}{*}{$\begin{array}{c}\text { SW } \\
\text { Usta 1989; Kirci } \\
\text { 1991; Kirci et al. } \\
\text { 2002, 2010 } \\
\text { Wood }\end{array}$} & \multirow{3}{*}{$\begin{array}{c}\text { HW } \\
\text { Tank 1978; Kirci } \\
\text { 1987; Akgül and } \\
\text { Kırcı 2002; Gulsoy } \\
2003 \\
\text { Wood }\end{array}$} \\
\hline & \multicolumn{2}{|c|}{ Yazıcı 2002} & \multirow{2}{*}{$\begin{array}{l}\text { Yasar et } \\
\text { al. } 2016 \\
\text { Wood }\end{array}$} & & \\
\hline & Wood & Bark & & & \\
\hline $\begin{array}{c}\text { Amount of } \\
\text { Holocellulose }\end{array}$ & 71.7 & 60.7 & 73.26 & 71.83 & 73.37 \\
\hline Amount of Cellulose & 44.0 & 31.5 & 53.59 & 53.6 & 47.67 \\
\hline $\begin{array}{l}\text { Amount of } \alpha- \\
\text { cellulose }\end{array}$ & & - & 43.28 & 48.5 & 45.5 \\
\hline Amount of Lignin & 23.2 & 29.7 & 21.19 & 27.2 & 22.4 \\
\hline
\end{tabular}

The average density of IC used as raw material is $620 \mathrm{~kg} / \mathrm{m}^{3}$, and the average density of BWC is $610 \mathrm{~kg} / \mathrm{m}^{3}$. The bulk densities of the particles were calculated according to TS EN ISO 17828 (2016) standard methods. Bulk density was $224 / 146 \mathrm{~kg} / \mathrm{m}^{3}$ for IC and $255 / 229 \mathrm{~kg} \mathrm{~m}^{3}$ for BWC values correspond to face/core layer respectively. 


\section{Methods}

A traditional three-layer particleboard production method was used to produce test panels. Forty percent of the total chip amount was used in the surface layers (bottom-top), and $60 \%$ was used in the middle layer. The panel thickness was $16 \mathrm{~mm}$, and the target density was $600 \mathrm{~kg} / \mathrm{m}^{3}$. It is produced in the size of $400 * 400 \mathrm{~mm}$, and after the edges were removed, it remained $360 * 360 \mathrm{~mm}$. The UF glue was applied as $8 \%$ for the middle layer and $10 \%$ for the surface layers based on dry weight of chips, and the hot-press conditions were set to $180{ }^{\circ} \mathrm{C}, 16$ to $18 \mathrm{MPa}$ specific press pressure, and 5 min press duration. The mixing ratios were determined in proportion to the raw material weight, and they were used in this way in order to determine the effect of BWC addition on the panel properties and the optimum usage ratio (Table 2). In addition, it was considered as sufficient to produce 3 boards for each experimental group to ensure homogeneous distribution in determining the board properties. BWC was used as shelled and the bark ratio in the total $\mathrm{BWC}$ raw material is $8 \%$.

Table 2. Mixing Ratio of Experimental Groups

\begin{tabular}{|c|c|c|c|}
\hline $\begin{array}{c}\text { Experimental } \\
\text { Group }\end{array}$ & Code & $\begin{array}{c}\text { BWC } \\
(\%)\end{array}$ & IC (\%) \\
\hline A & $\% 100$ BWC & 100 & 0 \\
\hline B & $\% 100$ IC & 0 & 100 \\
\hline C & $\% 25 B W C+\% 75 I C$ & 25 & 75 \\
\hline D & $\% 50 B W C+\% 50 I C$ & 50 & 50 \\
\hline E & $\% 75 B W C+\% 25 I C$ & 75 & 25 \\
\hline
\end{tabular}

\section{Preparation of wood raw material}

For production of the test panels, the sweet bay wood that was provided in small pieces from the bay leaf production facility was largely free of foreign materials and large pieces unsuitable for flaking. Then, it was passed through a laboratory scale chipper and made suitable for screening and classification. In the production of the three-layer particleboard, a sieving and classification process was performed to obtain surface layers and middle-layer chips.

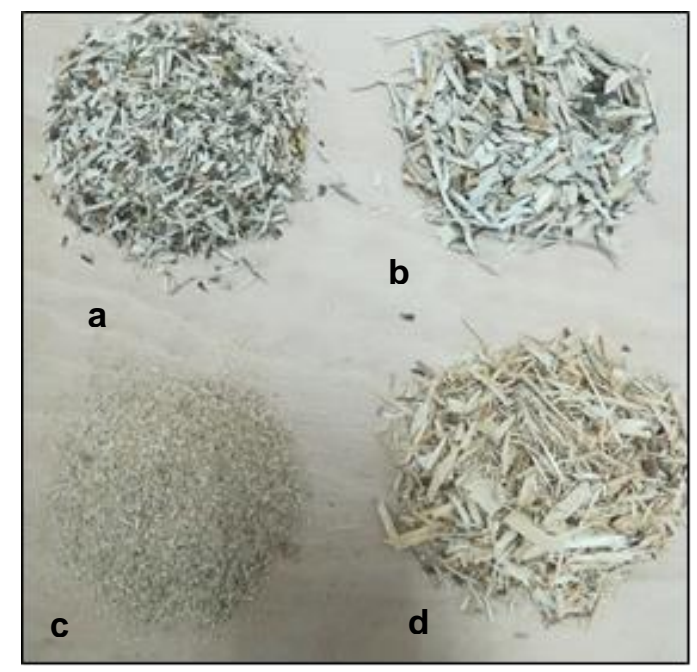

Fig. 1. The middle and surface layer chips: a: BWC (Surface), b: BWC (Medium), c: IC (Surface), and d: IC (Medium) 
Chips that passed through a 9-mm screen but failed to pass through a 2.36-mm screen were used in the middle layer, and chips that passed through a $2.36-\mathrm{mm}$ screen but failed to pass through a 1-mm screen were used as the surface layers (Fig. 1). In contrast, industrial chips were not subjected to any screening process because it was ready for production as supplied. Then, the chips were dried at $103{ }^{\circ} \mathrm{C}$ for an average of $2 \mathrm{~h}$, which allowed the moisture content to reach the $1 \%$ to $3 \%$ range.

\section{Production of test panels}

The middle layer and surface layer chips of a suitable moisture content were taken to the rotary drum mixer to be glued with the help of a spray gun. After the gluing process, the specified amount of chips was placed in the mold with three layers, and a hot press (SSP 180; Cemil Usta, İstanbul, Turkey) was applied after pre-pressing. The panel produced by the hot press was kept in the laboratory environment on the shelves to be cooled (Fig. 2a). The distribution of sweet bay wood (BWC) in board sections can be seen in Fig. $2 b$.
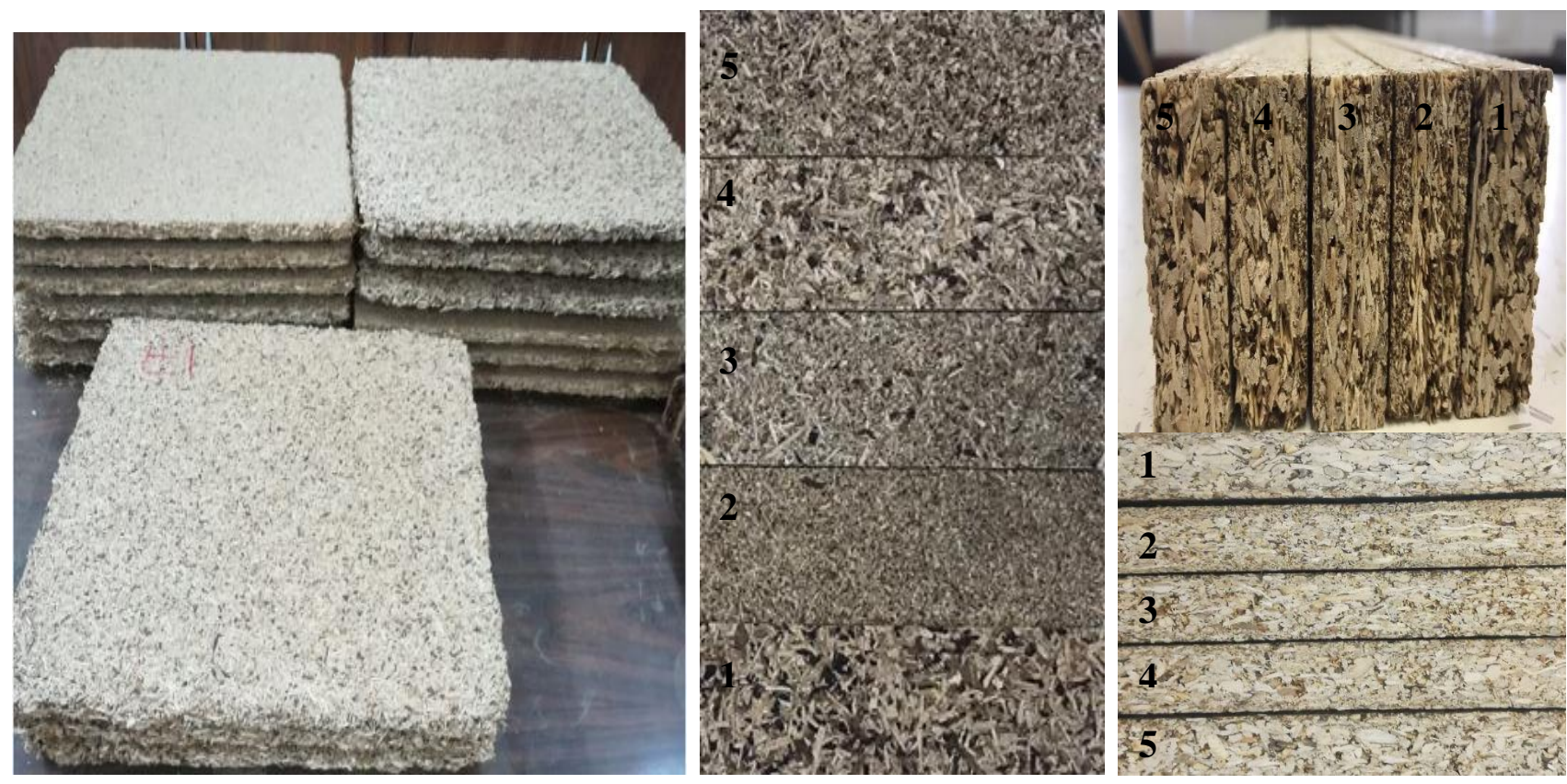

Fig. 2. a: Experimental boards, b: BWC distributions in different sections: 1: \%100 BWC, 2: \%100 IC: 3: \%25BWC + \%75IC, 4: \%50BWC + \%50IC, 5: \%75BWC + \%25IC

\section{Determination of panel properties}

After the test panels were conditioned $20 \pm 2{ }^{\circ} \mathrm{C}$ at $65 \pm 5 \% \mathrm{RH}$ for 2 weeks conditions, the physical properties of moisture $(r)$, density $(d)$, and water absorption (WA) at $2 \mathrm{~h}$ and $24 \mathrm{~h}$ and thickness swelling (TS) were determined. In addition, bending strength (BS), modulus of elasticity (MOE), and internal bonding perpendicular to the surface (IB) were determined. In addition, formaldehyde emission of test boards were determined according to the TS EN ISO 12460-5 (2016) perforator method. The experiments were conducted in accordance with the standards given in Table 3. Fifteen measurements were carried out for each experiment as 5 per board. In addition, the experimental results were evaluated by one-way analysis of variance (ANOVA) in the SPSS program (Version 16, IBM Corp., Redmond, NY, USA), and the differences between the groups were determined 
by Duncan's homogeneity test. Findings related to physical and mechanical properties were evaluated according to TS EN 312 (2012).

Table 3. Test Standards for Physical and Mechanical Properties

\begin{tabular}{|c|c|}
\hline Properties & Test Standard \\
\hline Moisture & TS EN 322 (1999) \\
\hline Density & TS EN 323 (1999) \\
\hline Water absorption and thickness swelling & TS EN 317 (1999) \\
\hline Bending strength and modulus of elasticity & TS EN 310 (1999) \\
\hline Internal bonding & TS EN 319 (1999) \\
\hline Preparation of test samples & TS EN 326 (1999) \\
\hline Particleboard specifications & TS EN 312 (2012) \\
\hline
\end{tabular}

\section{RESULTS AND DISCUSSION}

\section{Physical Properties}

The average values and standard deviation values of several physical properties of test panels produced with different rates of bay wood waste chips and industrial wood chip mixtures are shown in Table 4. According to Table 4, the moisture content values of all panel groups complied with TS EN 312 (2012). When the target density value $\left(600 \mathrm{~kg} / \mathrm{m}^{3}\right)$ was taken into consideration, the values obtained were within the $10 \%$ tolerance limit specified by TS EN 312 (2012). In addition, there was no statistically significant difference in density value between the panel groups. İstek and Siradağ (2013) stated that density changes up to $10 \%$ in particleboards have no significant effect on board properties.

Table 4. Some Physical Properties of Test Panels

\begin{tabular}{|c|c|c|c|c|c|c|c|}
\hline Group & Content & $\begin{array}{c}\boldsymbol{r} \\
(\%)\end{array}$ & $\begin{array}{c}\boldsymbol{d} \\
\left(\mathbf{k g} / \mathbf{m}^{3}\right)\end{array}$ & $\begin{array}{c}\mathbf{2} \mathbf{h} \text { TS } \\
(\%)\end{array}$ & $\begin{array}{c}\mathbf{2 4} \mathbf{h} \text { TS } \\
(\%)\end{array}$ & $\begin{array}{c}\mathbf{2} \mathbf{h} \text { WA } \\
(\%)\end{array}$ & $\begin{array}{c}\mathbf{2 4} \mathbf{h} \text { WA } \\
(\%)\end{array}$ \\
\hline \multirow{2}{*}{$\mathbf{A}$} & $\% 100 \mathrm{BWC}$ & $5.35 \pm$ & $650 \pm$ & $51.21 \pm$ & $57.07 \pm$ & $83.20 \pm$ & $105.60 \pm$ \\
& & $0.07 \mathbf{b}$ & $45 \mathbf{a}$ & $3.16 \mathbf{d}$ & $3.96 \mathbf{d}$ & $4.62 \mathbf{b}$ & $4.09 \mathbf{c}$ \\
\hline \multirow{2}{*}{ B } & $\% 100 \mathrm{IC}$ & $5.34 \pm$ & $640 \pm$ & $33.75 \pm$ & $36.40 \pm$ & $87.59 \pm$ & $98.43 \pm$ \\
& & $0.15 \mathbf{b}$ & $50 \mathbf{a}$ & $2.93 \mathbf{a}$ & $3.23 \mathbf{a}$ & $5.04 \mathbf{c}$ & $4.86 \mathbf{a}$ \\
\hline \multirow{2}{*}{$\mathbf{C}$} & $\% 25 \mathrm{BWC}+$ & $5.21 \pm$ & $640 \pm$ & $42.87 \pm$ & $46.54 \pm$ & $84.61 \pm$ & $99.59 \pm$ \\
& $\% 75 \mathrm{IC}$ & $0.13 \mathbf{a}$ & $43 \mathbf{a}$ & $5.76 \mathbf{b}$ & $5.70 \mathbf{b}$ & $4.11 \mathbf{b c}$ & $4.36 \mathbf{a}$ \\
\hline \multirow{2}{*}{$\mathbf{D}$} & $\% 50 \mathrm{BWC}+$ & $5.16 \pm$ & $650 \pm$ & $45.95 \pm$ & $50.88 \pm$ & $87.42 \pm$ & $103.41 \pm$ \\
& $\% 50 \mathrm{IC}$ & $0.09 \mathbf{a}$ & $42 \mathbf{a}$ & $3.32 \mathbf{c}$ & $3.70 \mathbf{c}$ & $3.13 \mathbf{c}$ & $3.91 \mathbf{b c}$ \\
\hline E & $\% 75 \mathrm{BWC}+$ & $5.00 \pm$ & $630 \pm$ & $41.78 \pm$ & $46.42 \pm$ & $78.01 \pm$ & $100.58 \pm$ \\
& $\% 25 \mathrm{IC}$ & $0.15 \mathbf{a}$ & $47 \mathbf{a}$ & $2.95 \mathbf{b}$ & $4.29 \mathbf{b}$ & $4.79 \mathbf{a}$ & $4.36 \mathbf{a b}$ \\
\hline
\end{tabular}

\pm : Standard deviation; Means followed by the same letters (a, b, and c) in the same column are not significantly $(\mathrm{p}<0.05)$ different

Examination of the TS values of the panel groups showed that there was a similar order for $2 \mathrm{~h}$ and $24 \mathrm{~h}$. The lowest TS values of group B panels for $2 \mathrm{~h}$ and $24 \mathrm{~h}$ were $33.8 \%$ and $36.4 \%$, respectively. For group A panels, the highest TS values were 51.2\% and $57.1 \%$, respectively. In addition, there was no statistically significant difference in TS between groups $\mathrm{C}$ and $\mathrm{E}$ for $2 \mathrm{~h}$ and $24 \mathrm{~h}$. Unlike TS, WA values were not similar for $2 \mathrm{~h}$ and $24 \mathrm{~h}$, and the lowest values were seen on group E (78.0\%) and group B (98.4\%) panels for $2 \mathrm{~h}$ and $24 \mathrm{~h}$, respectively. A statistically significant difference was found between the E group 
panels and the other groups for the highest values for $2 \mathrm{~h}$ WA. The $2 \mathrm{~h}$ and $24 \mathrm{~h}$ TS rates of the panel groups are shown in Fig. 3.

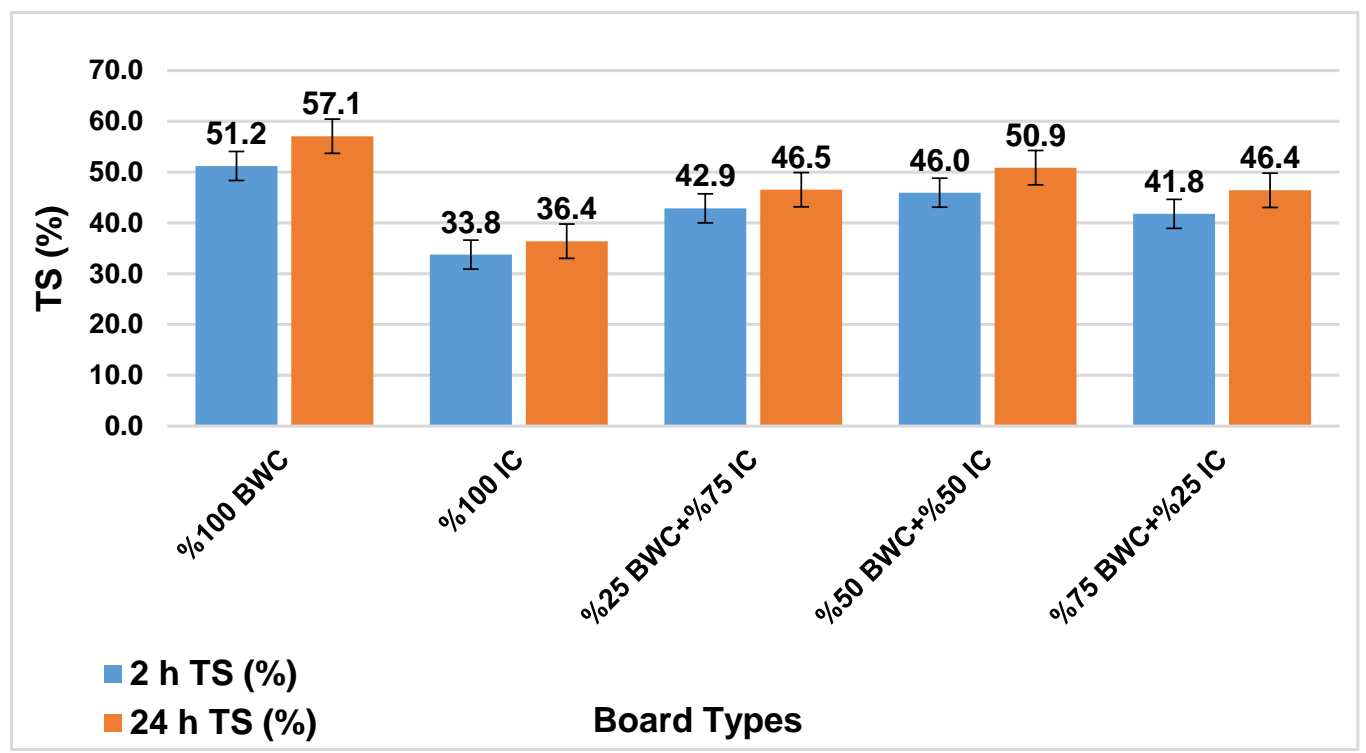

Fig. 3. Thickness swelling at $2 \mathrm{~h}$ and $24 \mathrm{~h}$

Figure 3 shows that there was a nonlinear increase in the rate of BWC usage and 2 $\mathrm{h}$ and $24 \mathrm{~h}$ TS rates. Two $\mathrm{h}$ TS values were between $33.8 \%$ and $51.2 \%$, and $24 \mathrm{~h}$ TS values ranged from $36.4 \%$ to $57.1 \%$. The 24 -h TS values obtained did not meet the standard value specified for non-load bearing boards used in humid conditions (TS EN 312 2012). However, as there is no requirement for TS value in boards used for general purposes (P1) and interior applications (P2) in dry conditions, the boards are suitable for general purposes. In addition, the dimensional stability of the boards will increase with the use of a water repellent additive, such as paraffin. Analysis of the dimensional stability properties of the panel groups according to BWC and IC usage rates revealed that the high usage rate of IC for TS showed a positive effect, and lower WA results were obtained with the use of BWC. Because BWC chips were obtained from a laboratory environment, they were shorter and thicker than the IC chips. This may have prevented the homogeneous gluing of chips, especially in experimental groups where BWC and IC were used as a mixture. This situation may have affected the amount of water they took into their structure. However, owning to the lignin in the bark structure, it has a water repellent effect and BWC barks have a higher lignin content than wood. It is considered that different consequences occur when BWC barks are not homogeneously distributed on board layers. The decrease in TS value in $75 \% \mathrm{BWC}+25 \% \mathrm{IC}$, which has the lowest density among the board groups, may be explained by the high porosity and the lack of bark presence. The obtained WA and TS values were higher than the standard values and results obtained in similar studies in the literature. This may be a result of not using a water repellent additive in the production of test panels, as well as the amount of glue used, chip geometry and other factors in the production of panels. In addition, other studies have reported that density affects dimensional stability (Zheng et al. 2005; Barboutis and Philippou 2007; Nazerian et al. 2011; İstek et al. 2018b). 


\section{Mechanical Properties}

The average values and the standard deviation values for some mechanical properties and formaldehyde emission of test panels are shown in Table 5.

Table 5. Mechanical Properties and Formaldehyde Emission of the Test Boards

\begin{tabular}{|c|c|c|c|c|c|}
\hline Group & Content & $\begin{array}{c}\text { BS } \\
\left(\mathrm{N} / \mathrm{mm}^{2}\right)\end{array}$ & $\begin{array}{c}\text { MOE } \\
\left(\mathrm{N} / \mathbf{m m}^{2}\right)\end{array}$ & $\begin{array}{c}\text { IB } \\
\left(\mathrm{N} / \mathrm{mm}^{2}\right)\end{array}$ & $\begin{array}{c}\text { Formaldehyde } \\
\text { emission } \\
\text { (mg/100g) }\end{array}$ \\
\hline A & $\% 100$ BWC & $\begin{array}{c}10.2 \pm \\
1.5 a\end{array}$ & $1936 \pm 144 b c$ & $0.35 \pm 0.16 b$ & 1.77 \\
\hline B & $\% 100$ IC & $\begin{array}{c}11.0 \pm \\
1.1 \mathrm{a} \\
\end{array}$ & $1621 \pm 155 a$ & $0.24 \pm 0.54 a$ & 3.31 \\
\hline C & $\begin{array}{l}\% 25 B W C+ \\
\% 75 I C\end{array}$ & $\begin{array}{l}10.9 \pm \\
2.0 a\end{array}$ & $1708 \pm 211 a b$ & $0.20 \pm 0.71 a$ & 4.30 \\
\hline D & $\begin{array}{l}\% 50 \mathrm{BWC}+ \\
\% 50 \mathrm{IC}\end{array}$ & $\begin{array}{l}10.2 \pm \\
1.7 a\end{array}$ & $1732 \pm 235 a b$ & $0.26 \pm 0.20 a$ & 2.54 \\
\hline E & $\begin{array}{l}\% 75 B W C+ \\
\% 25 I C\end{array}$ & $\begin{array}{l}10.3 \pm \\
2.9 a\end{array}$ & $2067 \pm 174 c$ & $0.35 \pm 0.84 b$ & 2.42 \\
\hline $\begin{array}{l}\text { Board } \\
\text { Class }\end{array}$ & \multicolumn{5}{|c|}{ Requirements for TS EN 312 (2012) } \\
\hline P1 & & 10 & * & 0.24 & $\mathrm{E} 1: \leq 8$ \\
\hline $\mathbf{P 2}$ & & 11 & 1600 & 0.35 & $E 2 \geq 30$ \\
\hline P3 & & 14 & 1950 & 0.45 & \\
\hline \multicolumn{5}{|c|}{$\begin{array}{l}\text { 土: Standard deviation } \\
\text { Means followed with the same letters }(a, b, \text { and } c) \text { in the same column are } \\
\text { not significantly }(p<0.05) \text { different. } \\
\text { * : No value specified } \\
\text { P1: General purpose boards used in dry conditions; P2: Indoor equipment } \\
\text { (including furniture) boards used in dry conditions; P3: Non-load-bearing } \\
\text { boards used in humid conditions }\end{array}$} & \\
\hline
\end{tabular}

Table 5 shows that there was no statistically significant difference between the BS values of the panel groups. In addition, all experimental groups for BS met the P1 standard of TS EN 312 (2012). The highest and lowest MOE values were $2070 \mathrm{~N} / \mathrm{mm}^{2}$ and 1620 $\mathrm{N} / \mathrm{mm}^{2}$, which were in group E and group B, respectively. In addition, the value obtained from the $\mathrm{E}$ group met the $\mathrm{P} 3$ panel class requirement, and all the experimental groups met the MOE requirements of P2 class panels (TS EN 312 2012). The IB values of the experimental groups ranged from $0.20 \mathrm{~N} / \mathrm{mm}^{2}$ to $0.35 \mathrm{~N} / \mathrm{mm}^{2}$. The highest IB value was obtained in group A and group E groups $\left(0.35 \mathrm{~N} / \mathrm{mm}^{2}\right)$, and the lowest value was found in group $C\left(0.20 \mathrm{~N} / \mathrm{mm}^{2}\right)$. However, there was no statistically significant difference between groups B, C, and D. According to TS EN 312 (2012), the results obtained from the A and E experimental groups met the $\mathrm{P} 2$ standard, and the $\mathrm{B}$ and $\mathrm{D}$ groups met the required values for the P1 panel class. The IB value of the group C panels was below the required value (TS EN 312 (2012). In general, the mechanical properties observed were in line with the literature. However, many factors, such as density, bark presence, chip geometry, and distribution, affect the physical and mechanical properties (Nemli 2003; Pan et al. 2007; Özlüsoylu and İstek 2018; İstek et al. 2020). In this study, there were significant differences between some panel densities, and the fact that some BWC was used in bark form may have affected the mechanical properties. It is thought that the amount of lignin in the bark may affect the mechanical properties (Guler and Yașar 2018; Kowaluk et al. 2019). In addition, in terms of chip geometry, the BWC obtained with a laboratory-type chipper had 
a different structure than ready-made IC (Nasser 2012). In addition, in different studies, the amount of wood components, such as cellulose, $\alpha$-cellulose, and lignin, has been found to affect certain physical and mechanical properties (Zayed et al. 2015; Guler and Yașar 2018). Since formaldehyde emission is mainly related to glue type and amount of use, it has been determined that there were no significant differences between the groups, except $25 \% \mathrm{BWC}+75 \% \mathrm{IC}$, with increasing $\mathrm{BWC}$ usage rate and a decrease in formaldehyde emission. It is also stated that different wood type (Demirkir et al. 2011) and wood pH (Çolak and Çolakoğlu 2004) and the waiting time of the boards have an effect on the formaldehyde emission (Siradağ 2020).

\section{CONCLUSIONS}

1. The moisture and density values of the test panels complied with TS EN 312 (2012).

2. The thickness swelling (TS) values obtained for $100 \%$ waste sweet bay wood chips (BWC) showed statistically significant improvement with the use of $75 \% \mathrm{BWC}+25 \%$. In addition, although TS and water absorption (WA) values were higher than the standard values and similar studies in the literature, the panels produced were suitable for general purposes.

3. All groups except group $\mathrm{P}(25 \% \mathrm{BWC}+75 \%)$ met the $\mathrm{P} 1$ panel class requirement, and group A $(100 \% \mathrm{BWC})$ and group $\mathrm{E}(75 \% \mathrm{BWC}+25 \% \mathrm{IC})$ met the required value for the P2 panel class. For modulus of elasticity (MOE), the E group $(75 \% \mathrm{BWC}+25 \%$ IC) also met the $\mathrm{P} 3$ panel class requirement.

4. The results showed that BWC could be used in the production of particleboards, and the obtained panels were suitable for general purposes, including furniture. In addition, the $75 \% \mathrm{BWC}+25 \%$ usage rate was the most suitable in terms of physical and mechanical properties.

5. Through utilizing BWC, which is considered a waste product, in the production of particleboard, a value-added product was obtained that both saved primary wood raw material and provided an environmental benefit. In addition, the continued increase in number and capacity of bay leaf production facilities in Turkey will contribute to the continued use of BWC as raw material.

\section{REFERENCES CITED}

Akgül, M., and Çamlibel, O. (2008). "Manufacture of medium density fiberboard (MDF) panels from rhododendron (R. ponticum L.) biomass," Building and Environment 43(4), 438-443. DOI: 10.1016/j.buildenv.2007.01.003

Akgül, M., and Kırcı, H. (2002). "Kavak odunundan etanol-su yöntemiyle çözünebilir hamur üretimi olanaklarının araştırılması [Investigation of soluble pulp production possibilities by using ethanol - water method from poplar wood]," KSU Journal of Science and Engineering 5(1), 72-85.

Akgül, M., and Tozluoğlu, A. (2008). "Utilizing peanut husk (Arachis hypogaea L.) in the manufacture of medium-density fiberboards," Bioresource Technology 99(13), 5590-5594. DOI: 10.1016/j.biortech.2007.10.041 
Alma, M. H., Kalaycioğlu, H., Bektaş, A., and Tutus, A. (2005). "Properties of cotton carpel-based particleboards," Indunstrial Crops and Products 22(2), 141-149. DOI: 10.1016/j.indcrop.2004.08.001

Arslan, M. B. (2008). Surface Chemical Properties of Forest and Agriculture Residue Based Composites Investigated, Master's Thesis, Suleyman Demirel University, Isparta, Turkey. (In Turkish)

Barboutis, J. A., and Philippou, J. L. (2007). "Evergreen Mediterranean hardwoods as particleboard raw material," Building and Environment 42(3), 1183-1187. DOI: 10.1016/j.buildenv.2005.07.053

Bardak, S., Nemli, G., Sari, B., Baharoglu, M., and Zekovic, E. (2010). "Manufacture and properties of particleboard composite from waste sanding dusts," High Temperature Materials and Processes 29(3), 159-168. DOI: 10.1515/HTMP.2010.29.3.159

Batalla, L., Nunez, A. J., and Marcovich, N. E. (2005). "Particleboards from peanut-shell flour," Journal of Applied Polymer Science 97(3), 916-923. DOI: 10.1002/app.21847

Cai, Z., Wu, Q., Lee, J. N., and Hiziroglu, S. (2004). "Influence of board density, mat construction, and chip type on performance of particleboard made from eastern redcedar," Forest Products Journal 54(12), 226-232.

Ciannamea, E. M., Stefani, P. M, and Ruseckaite, R. A. (2010). "Medium-density particleboards from modified rice husks and soybean protein concentrate-based adhesives," Bioresource Technology 101(2), 818-825. DOI:

10.1016/j.biortech.2009.08.084

Clausen, C. A. (2000). "CCA removal from treated wood using a dual remediation process," Waste Management and Research 18(5), 485-488. DOI: 10.1034/j.13993070.2000.00151.x

Çolak, S., and Çolakoğlu, G. (2004). "Volatile acetic acid and formaldehyde emission from plywood treated with boron compound," Building and Environment 39(5) 533536. DOI: 10.1016/j.buildenv.2003.08.019

Çöpür, Y., Güler, C., Akgül, M., and Taşçıŏlu, C. (2007). "Some chemical properties of hazelnut husk and its suitability for particleboard production," Building and Environment 42(7), 2568-2572. DOI: 10.1016/j.buildenv.2006.07.011

de Lima Mesquita, A., Barrero, N. G., Fiorelli, J., Christoforo, A. L., De Faria, L. J. G., and Lahr, F. A. R. (2018). "Eco-particleboard manufactured from chemically treated fibrous vascular tissue of acai (Euterpe oleracea Mart.) Fruit: A new alternative for the particleboard industry with its potential application in civil construction and furniture," Industrial Crops and Products 112, 644-651. DOI:

10.1016/j.indcrop.2017.12.074

Demirkır, C., Çolakoğlu, G., Aydın, İ., and Çolak, S. (2011). "Effect of wood species used for core layer on some properties of okume plywood panels bonded with melamine-urea formaldehyde (MUF) adhesive," Journal of Artvin Çoruh University Faculty of Forestry 6(1), 94-101.

Dos Santos, M. F. N., Battistelle, R. A. G., Bezerra, B. S., and Varum, H. S. (2014). "Comparative study of the life cycle assessment of particleboards made of residues from sugarcane bagasse (Saccharum spp.) and pine wood shavings (Pinus elliottii)," Journal of Cleaner Production 64, 345-355. DOI: 10.1016/j.jclepro.2013.06.039

El-Mously, H. I., Megahed, M. M., and Rakha, M. M. (1999). "Investigation of the possibility of use of cotton stalks in particleboard manufacture," Scientific Bulletin of the Faculty of Engineering, Ain-Shams University, ISSN 1110-1385, 34(4): 589-610.. 
El-Mously, H., El-Morshedy, M. M., Megahed, M. M., and El-Hai, Y. A. (1993). "Evaluation of particleboard made of palm leaves midribs as compared with flax board," in: Proceedings of the $4^{\text {th }}$ International Conference on Production Engineering and Design for Development, Cairo, Egypt, pp. 27-29.

Filiz, M., Usta, P., and Şahin, H. T. (2011). "Evaluation of some technical properties obtained from the participleboard with melamine urea formaldehyde glue, red pine and tea waste," Süleyman Demirel University Journal of Natural and Applied Sciences 15(2), 88-93.

Fiorelli, J., Curtolo, D. D., Barrero, N. G., Savastano, H. J., Pallone, E. M. A., and Johnson, R. (2012). "Particulate composite based on coconut fiber and castor oil polyurethane adhesive: An eco-efficient product," Industrial Crops and Products 40, 69-75. DOI: 10.1016/j.indcrop.2012.02.033

García-Ortuño, T., Andreu, J., García, M. T. F., Ferrández-Villena, M., and FerrandezGarcia, C. E. (2011). "Evaluation of the physical and mechanical properties of particleboard made from giant reed (Arundo donax L.)," BioResources 6(1), 477-486. DOI: 10.15376/biores.6.1.477-486

Gökmen, H. (1973). Kapalı Tohumlular Angiospermae [Angiosperms], Technical report Forestry Directorate of Turkey (OGM) No. 564/53. Şark Publication, Ankara, Turkey.

Grigoriou, A., Passialis, C., and Voulgaridis, E. (2000). "Experimental particleboards from Kenaf plantations grown in Greece," Holz als Roh- und Werkstoff 58(5), 309314. DOI: $10.1007 / \mathrm{s} 001070050435$

Grigoriou, A. H., and Ntalos, G. A. (2001). "The potential use of Ricinus communis L. (castor) stalks as a lignocellulosic resource for particleboards," Industrial Crops and Products 13(3), 209-218. DOI: 10.1016/S0926-6690(00)00078-9

Guler, C., and Büyüksarı, Ü. (2011). "Effect of production parameters on the physical and mechanical properties of particleboards made from peanut (Arachis hypogaea L.) hull," BioResources 6(4), 5027-5036. DOI: 10.15376/biores.6.4.5027-5036

Guler, C., and Ozen, R. (2004). "Some properties of particleboards made from cotton stalks (Gossypium hirsitum L.)," Holz als Roh-und Werkstoff 62(1), 40-43. DOI: 10.1007/s00107-003-0439-9

Guler, C., Bektas, I., and Kalaycioglu, H. (2006). "The experimental particleboard manufacture from sunflower stalks (Helianthus annuus L.) and Calabrian pine (Pinus brutia Ten.)," Forest Products Journal 56(4), 56-60.

Guler, C., Çöpür, Y., and Tascioglu, C. (2008). "The manufacture of particleboards using mixture of peanut hull (Arachis hypogaea L.) and European black pine (Pinus nigra Arnold) wood chips," Bioresource Technology 99(8), 2893-2897. DOI: 10.1016/j.biortech.2007.06.013

Guler, G., and Beram, A. (2018). "Investigation of physical, mechanical and surface roughness properties of particleboards produced from chicory (Cichorium intybus L.) stalks," Journal of Bartin Faculty of Forestry 20(2), 216-222. DOI: 10.24011/barofd.426424 (In Turkish)

Guler, G., and Yașar, S. (2018). "Investigation of some chemical properties of kermes oak (Quercus coccifera L.) wood and its use in the particleboard production," Journal of Bartin Faculty of Forestry 20(2), 184-193.

Guler, S., and Basaran, S. (2003). Determination of the Rehabilitation Technique for Degraded Laurel Areas (A Case Study: Manavgat-Yaylaalan) (ODC: 25) Southwest Anatolia Forest Research Institute (SAFRI) No: 69 p.44, Antalya, Turkey 
Gulsoy, S. K. (2003). Investigation of Chemical and Anatomical Structures, Fiber Morphology and Paper Characterisrics of Cancerous and Normal Tissues of Several Softwood Species, Master's Thesis, Zonguldak Karaelmas University, Zonguldak, Turkey.

Guntekin, E., and Karakus, B. (2008). "Feasibility of using eggplant (Solanum melongena) stalks in the production of experimental particleboard," Industrial Crops and Products 27(3), 354-358. DOI: 10.1016/j.indcrop.2007.12.003

Guntekin, E., Uner, B., and Karakus, B. (2009). "Chemical composition of tomato (Solanum lycopersicum) stalk and suitability in the particleboard production," Journal of Environmental Biology 30(5), 731-734.

Gürü, M., Tekeli, M., and Bilici, I. (2006). "Manufacturing of urea-formaldehyde-based composite particleboard from almond shell," Materials \& Design 27(10), 1148-1151. DOI: 10.1016/j.matdes.2005.03.003

Halvarsson, S., Edlund, H., and Norgren, M. (2008). "Properties of medium-density fibreboard (MDF) based on wheat straw and melamine modified urea formaldehyde (UMF) resin," Industrial Crops and Products 28(1), 37-46. DOI: 10.1016/j.indcrop.2008.01.005

Han, G., Zhang, C., Zhang, D., Umemura, K., and Kawai, S. (1998). "Upgrading of urea formaldehyde-bonded reed and wheat straw particleboards using silane coupling agents," Journal of Wood Science 44(4), 282-286. DOI: 10.1007/BF00581308

Hegazy, S. S., and Aref, I. M. (2010). "Suitability of some fast-growing trees and date palm fronds for particleboard production," Forest Products Journal 60(7), 599-604. DOI: $10.13073 / 0015-7473-60.7 .599$

İstek A., and Siradağ, H. (2013). "The effect of density on particleboard properties," in: International Caucasian Forestry Symposium, Artvin, Turkey, pp. 932-938.

İstek, A., Aydin, U., and Özlüsoylu, İ. (2019). "The effect of mat layers moisture content on some properties of particleboard," Drvna Industrija 70(3), 221-228. DOI: 10.5552/drvind.2019.1821

İstek, A., Gözalan, M., and Özlüsoylu, İ. (2017a). "The effects of surface coating and painting process on particleboard properties," Journal of Kastamonu Faculty of Forestry 17(4), 619-629. DOI: 10.17475/kastorman.180279

İstek, A., Özlüsoylu, İ., and Kizilkaya, A. (2017b). “Turkish wood based panels sector analysis," Journal of Bartın Faculty of Forestry 19(1), 132-138.

İstek, A., Özlüsoylu, İ., Onat, S. M., and Özlüsoylu, Ş. (2018a). "Formaldehyde emission problems and solution recommendations on wood-based boards," Journal of Bartın Faculty of Forestry 20(2), 382-387. DOI: 10.24011/barofd.425409

İstek, A., Aydın, U., and Özlusoylu, I. (2018b). "The effect of chip size on the particleboard properties," in: International Congress on Engineering and Life Science, Kastamonu, Turkey, pp. 439-444.

Iswanto, A. H., Azhar, I., Supriyanto, I., and Susilowati, A. (2014). "Effect of resin type, pressing temperature and time on particleboard properties made from sorghum bagasse," Agriculture, Forestry and Fisheries 3(2), 62-66. DOI: 10.11648/j.aff.20140302.12

Juliana, A. H., Paridah, M. T., Rahim, S., Azowa, I. N., and Anwar, U. M. K. (2012). "Properties of particleboard made from kenaf (Hibiscus cannabinus L.) as function of particle geometry," Materials \& Design 34, 406-411. DOI:

10.1016/j.matdes.2011.08.019

Kalaycioglu, H., Deniz, I., and Hiziroglu, S. (2005). "Some of the properties of 
particleboard made from paulownia," Journal of Wood Science 51(4), 410-414. DOI: 10.1007/s10086-004-0665-8

Kayacik, H. (1977). Orman ve Park A ğaçlarının Özel Sistematiği [Special Systematics of Forest and Park Trees], İ. Ü. Orman Fakültesi, İ.Ü. Yayın No: 2400, O. F. Yayın No: 247, İstanbul, Turkey, pp. 207-208.

Khedari, J., Nankongnab, N., Hirunlabh, J., and Teekasap, S. (2004). "New low-cost insulation particleboards from mixture of durian peel and coconut coir," Building and Environment 39(1), 59-65. DOI: 10.1016/j.buildenv.2003.08.001

Khristova, P., Yossifov, N., Gabir, S., Glavche, I. K., and Osman, Z. (1998). "Particleboards from sunflower stalks and tannin-modified UF resin," Cellulose Chemistry and Technology 32(3-4), 327-337.

Kılıç, A., Sarıusta, S. E., and Hafizoğlu, H. (2010). "Chemical structure of compression wood of Pinus sylvestris, P. nigra and P. brutia," Journal of Bartin Faculty of Forestry 12(18), 33-39.

Kirci, H. (1987). Yalancı Akasya (Robinia pseudoacacia L.) Odununun Kağıt Endüstrisinde Değerlendirilme Olanakları [Possibilities of Using Black Locust (Robinia pseudoacacia L.) Wood in Paper Industry], Master's Thesis, Karadeniz Technical University, Trabzon, Turkey. (In Turkish)

Kirci, H. (1991). Determination of Alkaline-sulfite-antroquinone-ethanol (ASAE) Pulping Conditions of Brutia Pine (Pinus brutia Ten), Ph.D. Dissertation, Karadeniz Technical University, Trabzon, Turkey.

Kirci, H., Ateş, S., and Boran S. (2002). “Anadolu Karaçamı (Pinus nigra subsp. Pallasiana) odunlarının asli hücre çeperi bileşenlerinin belirlenmesi ve kağıt hamuru üretimine uygunluğunun araştırılması [Determination of the main cell wall components of Black pine (Pinus nigra subsp. Pallasiana) woods and investigating their suitability for pulp production]," in: Proceedings of the II. National Black Sea Forestry Congress, Artvin, Turkey, pp.1057-1063

Kowaluk, G., Szymanowski, K., Kozlowski, P., Kukula, W., Sala, C., Robles, E., and Czarniak, P. (2020). "Functional assessment of particleboards made of apple and plum orchard pruning," Waste and Biomass Valorization 11, 2877-2886. DOI: $10.1007 / \mathrm{s} 12649-018-00568-8$

Kurt, R. (2020). "Determining the priorities in utilization of forest residues as biomass: An A'wot analysis," Biofuels, Bioproducts and Biorefining 14(2), 315-325. DOI: 10.1002/bbb.2077

Kurt, R., and Karay1lmazlar, S. (2019). "Estimating modulus of elasticity (MOE) of particleboards using artificial neural networks to reduce quality measurements and costs," Drvna Industrija 70(3), 257-263. DOI: 10.5552/drvind.2019.1840

Kurt, R., Karayilmazlar, S., İmren, E., and Cabuk, Y. (2016). "Non-wood forest products in Turkey forestry sector: Export analysis," Journal of Bartın Faculty of Forestry 18(2), 158-167. DOI: 10.24011/barofd.267289

Laemlaksakul, V. (2010). "Physical and mechanical properties of particleboard from bamboo waste," World Academy of Science, Engineering and Technology 40, 507511.

Lin, C. J., Hiziroglu, S., Kan, S. M., and Lai, H. W. (2008). "Manufacturing particleboard panels from betel palm (Areca catechu Linn.)," Journal of Materials Processing Technology 197(1-3), 445-448. DOI: 10.1016/j.jmatprotec.2007.06.048

Maloney, T. (1993). Modem Particleboard and Dry-process Fiberboard Manufacturing, U.S. Department of Agriculture Forest Products Laboratory, Madison, WI, USA. 
Meinlschmidt, P., Schirp, A., Dix, B., Thole, V., and Brinker, N. (2008). “Agricultural residues with light parenchyma cells and expandable filler materials for the production of lightweight particleboards," in: Proceedings of the International Panel Products Symposium, Espoo, Finland, pp. 179-188.

Mo, X., Cheng, E., Wang, D., and Sun, X. S. (2003). "Physical properties of medium density wheat straw particleboard using different adhesives," Industrial Crops and Products 18(1), 47-53. DOI: 10.1016/S0926-6690(03)00032-3

Mohamed, T. E., and Nasser, R. A. (2008). "Effect of mixing three lignocellulosic materials on some properties of particleboard bonded with urea formaldehyde adhesive," Journal of Agricultural Research of Kafer El-Sheikh University 34(4), 1144-1163.

Nasser, R. A. (2012). "Physical and mechanical properties of three-layer particleboard manufactured from the tree pruning of seven wood species," World Applied Sciences Journal 19(5), 741-753. DOI: 10.5829/idosi.wasj.2012.19.05.2764

Nazerian, M., Beyki, Z., Gargarii, R. M., and Kool, F. (2016). "The effect of some technological production variables on mechanical and physical properties of particleboard manufactured from cotton (Gossypium hirsutum) stalks," Maderas. Ciencia y Tecnología 18(1), 167-178. DOI: 10.4067/S0718-221X2016005000017

Nazerian, M., Ghalehno, M. D., Shojaiishad, M., Sharifpoor, H., and Taftiyan, M. H. (2011). "Properties of three-layer particleboard made from wood of Athel (Tamarix aphylla) and pruning particles of almond (Amygdalus communis) and pistachio (Pistacia vera)," Journal of Basic and Applied Scientific Research 1(8), 837-843.

Nemli, G. (2003). "Effects of some manufacturing factors on the properties of particleboard manufactured from alder (Alnus glutinosa subsp. Barbata)," Turkish Journal of Agriculture and Forestry 27(2), 99-104.

Nemli, G., and Kalaycioğlu, H. (1997). "An alternative material in particleboard industry: Residues of tea factory," in: Proceedings of The XI World Forestry Congress, Antalya, Turkey, pp. 49.

Ntalos, G. A., and Grigoriou, A. H. (2002). "Characterization and utilisation of vine prunings as a wood substitute for particleboard production," Industrial Crops and Products 16(1), 59-68. DOI: 10.1016/S0926-6690(02)00008-0

Onat, S. M., Kloeser, L., and Mai, C. (2014). “An amino-alkyl siloxane oligomer as hydrophobation agent for particleboards used under high humidity conditions," European Journal of Wood and Wood Products 72, 643-649. DOI: 10.1007/s00107014-0829-1

Özer, S. (1987). Ülkemizdeki Bazı Önemli Orman Tali Ürünlerinin Teşhis ve Tanıtım Kllavuzu. User Guide: [Diagnosis and Promotion Guide of Some Important Non Wood Forest Products in Turkey], Orman Genel Müdürlüğü Yayını, Yayın No: 659, Seri No: 18, Ankara, Turkey.

Özlüsoylu, İ., and İstek, A. (2018). "Sodyum karboksimetil selüloz (Na-CMC) takviyeli üre formaldehit tutkalının yonga levha özellikleri ve formaldehit emisyonuna etkisi [Effect of urea formaldehyde resin reinforced with sodium carboxymethylcellulose (Na- CMC) on particleboard properties and formaldehyde emission]," Türkiye Ormancılık Dergisi 19(3), 317-322. DOI: 10.18182/tjf.402355

Pan, Z., Zheng, Y., Zhang, R., and Jenkins, B. M. (2007). "Physical properties of thin particleboard made from saline eucalyptus," Industrial Crops and Products 26(2), 185-194. DOI: 10.1016/j.indcrop.2007.03.006 
Papadopoulos, A. N., Hill, C. A. S., Gkaraveli, A., Ntalos, G. A., and Karastergiou, S. P. (2004). "Bamboo chips (Bambusa vulgaris) as an alternative lignocellulosic raw material for particleboard manufacture," Holz als Roh-und Werkstoff 62(1), (36-39). DOI: $10.1007 / \mathrm{s} 00107-003-0447-9$

Papadopoulos, A. N., and Hague, J. R. B. (2003). "The potential for using flax (Linum usitatissimum L.) shiv as a lignocellulosic raw material for particleboard," Industiral Crops and Products 17(2), 143-147. DOI: 10.1016/S0926-6690(02)00094-8

Siradağ, H. (2019). Free Formaldehyde Change in Laminate Parquet Depending on the Waiting Time, Master's Thesis, Bartın University, Bartın, Turkey. (In Turkish)

Silva, M. R., Pinheiro, R. V., Christoforo, A. L., Panzera, T. H., and Lahr, F. A. R. (2018). "Hybrid sandwich particleboard made with sugarcane, pínus taeda thermally treated and malva fibre from amazon," Materials Research 21(1), 1-7. DOI: 10.1590/1980-5373-MR-2017-0724

Sugahara, E. S., da Silva, S. A. M., Buzo, A. L. S. C., de Campos, C. I., Morales, E. A. M., Ferreira, B. S., ... and Christoforo, A. L. (2019). "High-density particleboard made from agro-industrial waste and different adhesives," BioResources 14(3), 5162 5170 .

Tank, T. (1978). Türkiye Kayın ve Gürgen Türlerinin NSSC (Nötral Sülfit Yarıkimyasal) Metodu ile Değerlendirilmesi [Utilization of Turkish Beech and Hornbeam Species with NSSC (neutral sulfite semi-chemical) Method], İ.Ü. Orman Fakültesi Yayınlar1, No: 2326/231, İstanbul, Turkey.

Tansey, P. (1995). "Particleboard from rice straw," Xilon International 8(83), 43-48.

Topbaşl1, B., and Sevinçli, Y. (2017). "Lavanta sapı ve muz kabuğu kullanılarak üretilen yonga levhaların karşılaştırılması [The Comparison of Particle Boards Produced by Using Lavender Stem and Banana Peel]," Electronic Journal of Vocational Colleges 7(1), 47-53.

TS EN 310 (1999). "Wood-based panels-Determination of modulus of elasticity in bending and of bending strength," Turkish Standards Institution, Ankara, Turkey.

TS EN 312 (2012). "Particleboards-Specification," Turkish Standards Institution, Ankara, Turkey.

TS EN 317 (1999). "Particleboards and fibreboards- Determination of swelling in thickness after immersion in water," Turkish Standards Institution, Ankara, Turkey.

TS EN 319 (1999). "Particleboards and fibreboards- Determination of tensile strength perpendicular to the plane of the board," Turkish Standards Inst., Ankara, Turkey.

TS EN 322 (1999). "Wood-based panels- Determination of moisture content," Turkish Standards Institution, Ankara, Turkey.

TS EN 323 (1999). "Wood- Based panels- Determination of density," Turkish Standards Institution, Ankara, Turkey.

TS EN 326 (1999). "Wood- Based panels- Sampling, cutting and inspection- Part 1:

Sampling test pieces and expression of test results," Turkish Standards Institution, Ankara, Turkey.

TS EN ISO 12460-5 (2016). "Wood-based panels - Determination of formaldehyde release - Part 5: Extraction method (called the perforator method)," Turkish Standards Institution, Ankara, Turkey.

TS EN ISO 17828 (2016). "Solid biofuels - Determination of bulk density (ISO 17828:2015)," Turkish Standards Institution, Ankara, Turkey.

Turkish General Directorate of Forestry (2016). "Orman ve Su İşleri Bakanlığı Orman Genel Müdürlügüü, 2016-2020 Defne Eylem Planı," 
(https://www.ogm.gov.tr/ekutuphane/Yayinlar/Defne_Eylem_Plani.pdf), Accessed 04 May 2020

Usta, M. (1989). Sülfat Pişirmesinde Açı̆̆a çıkan Toplam Indirgenmiş Kükürt (TRS) Bileşiklerinin Oksijenle Yükseltgenmesi [Oxygen Oxidation of Total Reduced Sulfur (TRS) Compounds Released in Sulfate Cooking], Ph.D. Dissertation, Karadeniz Technical University, Trabzon, Turkey.

Valarelli, I. D. D., Battistelle, R. A. G., Bueno, M. A. P., Bezerra, B. S., Campos, C. I. D., and Alves, M. C. D. S. (2014). "Physical and mechanical properties of particleboard bamboo waste bonded with urea formaldehyde and castor oil based adhesive," Matéria (Rio de Janeiro) 19(1), 1-6. DOI: 10.1590/S151770762014000100002

Wang, D., and Sun, X. S. (2002). "Low density particleboard from wheat straw and corn pith," Industrial Crops and Products 15(1), 43-50. DOI: 10.1016/S09266690(01)00094-2

$\mathrm{Xu}, \mathrm{J} .$, Han, G., and Kawai, S. (2003). "Development of binderless particleboard from kenaf core using steam-injection pressing," Journal of Wood Science 49(4), 327-332. DOI: $10.1007 / \mathrm{s} 10086-002-0485-7$

$\mathrm{Xu}, \mathrm{X}$., Yao, F., Wu, Q., and Zhou, D. (2009). "The influence of wax-sizing on dimension stability and mechanical properties of bagasse particleboard," Industrial Crops and Products 29(1), 80-85. DOI: 10.1016/j.indcrop.2008.04.008

Yaşar, S., Ceviz, A. U., and Karatepe, Y. (2016). "Laurus nobilis, Vitex agnus-castus ve Tamarix parviflora türlerinin kimyasal içeriği ve fenolik ekstraktiflerinin incelenmesi [Investigation of Chemical Composition and Phenolic Extractives of Laurus nobilis, Vitexagnus-castus and Tamarix parviflora Species]," Süleyman Demirel University Journal of Natural and Applied Sciences 20(2), 182-187. DOI: 10.19113/sdufbed.21924

Yano, B. B. R., Silva, S. A. M., Almeida, D. H., de Moura Aquino, V. B., Christoforo, A. L., Rodrigues, E. F. C., and Lahr, F. A. R. (2020). "Use of sugarcane bagasse and industrial timber residue in particleboard production," BioResources 15(3), 47534762.

Yazıc1, H. (2002). The Investigation of the Utilization Possibilities of Bay Laurel (Laurus nobilis L.) Leaves and Fruits Grown in Western Black Sea Region, Ph.D. Dissertation, Zonguldak Karaelmas University, Zonguldak, Turkey.

Youngquist, J. A. (1999). "Wood-based composites and panel products," in: Wood Handbook: Wood as an Engineering Material, U.S. Department of Agriculture Forest Products Laboratory, Madison, WI, USA, pp. 10.1-10.31, 113.

Zayed, S. E., Adam, A. B. A., Hassan, E. A., and El-kady, M. A. (2015). "Renewable Egyptian lignocellulosic materials as alternative raw material for particleboard manufacturing," International J. of Innovation and Scientific Research 18, 262-272.

Zheng, Y., Pan, Z., Zhang, R., Jenkins, B. M., and Blunk, S. (2005). "Properties of medium-density particleboard from saline Athel wood," in: 2005 ASAE Annual Meeting, Tampa, Florida USA, pp. 1-15

Article submitted: May 19, 2020; Peer review completed: July 19, 2020; Revised version received and accepted: August 7, 2020; Published: September 10, 2020.

DOI: $10.15376 /$ biores. 15.4.8175-8190 